\title{
De groei en bloei van het bestuursrecht
}

Citation for published version (APA):

Stroink, F. A. M. (2006). De groei en bloei van het bestuursrecht. Sdu Uitgevers. https://doi.org/10.26481/spe.20060616fs

Document status and date:

Published: 16/06/2006

DOI:

$10.26481 /$ spe.20060616fs

Document Version:

Publisher's PDF, also known as Version of record

\section{Please check the document version of this publication:}

- A submitted manuscript is the version of the article upon submission and before peer-review. There can be important differences between the submitted version and the official published version of record.

People interested in the research are advised to contact the author for the final version of the publication, or visit the DOI to the publisher's website.

- The final author version and the galley proof are versions of the publication after peer review.

- The final published version features the final layout of the paper including the volume, issue and page numbers.

Link to publication

\footnotetext{
General rights rights.

- You may freely distribute the URL identifying the publication in the public portal. please follow below link for the End User Agreement:

www.umlib.nl/taverne-license

Take down policy

If you believe that this document breaches copyright please contact us at:

repository@maastrichtuniversity.nl

providing details and we will investigate your claim.
}

Copyright and moral rights for the publications made accessible in the public portal are retained by the authors and/or other copyright owners and it is a condition of accessing publications that users recognise and abide by the legal requirements associated with these

- Users may download and print one copy of any publication from the public portal for the purpose of private study or research.

- You may not further distribute the material or use it for any profit-making activity or commercial gain

If the publication is distributed under the terms of Article $25 \mathrm{fa}$ of the Dutch Copyright Act, indicated by the "Taverne" license above, 
De groei en bloei van het bestuursrecht 



\section{De groei en bloei van het bestuursrecht}

Afscheidsrede gehouden door

Prof.mr. F.A.M. Stroink

hoogleraar staats- en bestuursrecht

Universiteit Maastricht

op 16 juni 2006

ter gelegenheid van zijn emeritaat 
Meer informatie over deze en andere uitgaven kunt u verkrijgen bij:

Sdu Klantenservice

Postbus 20014

2500 EA Den Haag

tel.: (070) 3789880

fax: (070) 3789783

Sdu Uitgevers bv Den Haag, 2006

Onslagontwerp: Villa $Y$

Ontwerp binnenwerk: Boekopmaak Nettie Litjens, Maastricht

ISBN: 9012114586

NUR: 823

Alle rechten voorbehoudem. Alle auteursrechten en databankrechten ten aanzien van deze uitgave worden uitdrukkelijk voorbehouden. Deze rechten berusten bij Sdu Uitgevers bv.

Behoudens de in of krachtens de Auteurswet 1912 gestelde uitzonderingen, mag niets uit deze uitgave worden verveelvoudigd, opgeslagen in een geautomatiseerd gegevensbestand of openbaar gemaakt in enige vorm of op enige wijze, hetzij elektronisch, mechanisch, door fotokopieèn, opnamen of enige andere manier, zonder woorafgaande schriftelijke toestemming van de uitgever.

Voorzover het maken van reprografische verveelvoudigingen uit deze uitgave is toegestaan op grond van artikel $16 \mathrm{~h}$ Auteurswet 1912, dient men de daarvoor wettelijk verschuldigde vergoedingen te voldown alan de Stichting Reprorecht (Postbus 3060, 2130 KB Hoofddorp, www.reprorechtnln). Voor het ovememen van gedeelte(n) uit deze titgave in bloemlezingen, readers en andere compilatiewerken (nutikel 16 Auteurswet 19/2) dient men zich te wenden tot de Stichting PRO (Stichting Publicatie- en Reproductierechten Orgmisatie, postbus 3060,2130 KB Hoofddorp, www.cedar.nl/pro). Voor het overnemen van een gedecte van deze uitgave ten behoeve van commerciele doeleinden dient men zich to wenden tot de uitgever.

Hoewel aan cle totslandkoming van deze uitgave de uiterste zorg is besteed, kan voor de afwezigheid van eventuele (druk) fouten en onvolledigheden niet worden ingestaan en aanvaarden de auteur(s), redacteur(en) en uitgever deswege geen aansprakelijkheid voor de gevolgen van eventueel voorkomende fouten en onvolledigheden.

All rights reserved. No part of this publication may be reproduced, stored in a retrieval system, or transmitted in any form or by any means, electronic, mechanical, photocopying, recording or otherwise, without the publisher's prior consent.

While every effort has been made to ensure the reliability of the information presented in this publication, Sdu Uitgevers neither guarantees the accuracy of the data contained herein nor accepts responsibility for errors or omissions or their consequences. 


\title{
De groei en bloei van het bestuursrecht
}

\author{
Meneer de rector, dames en heren,
}

\section{Een beetje geschiedenis}

Precies veertig jaar geleden was ik op zoek naar een kamer in Leiden. Velen verkeerden toen nog in de veronderstelling dat je alleen in Leiden rechten kon studeren.

In die tijd, de tweede helft van de jaren zestig, stelde het verplichte onderdeel bestuursrecht in de studie niet zoveel voor. Je moest iets weten over attributie, delegatie en mandaat, van het beschikkingsbegrip, de onrechtmatige overheidsdaad en de wet BAB. beroep administratieve beschikkingen, de voorloper van de wet AROB. De verplichte stof bestond met name uit een aantal hoofdstukken van - toen nog - een dun boekje, het rapport ABAR, Algemene bepalingen van administratief recht.'

De afgelopen decennia heeft het bestuursrecht een enorme groei en bloei doorgemaakt. $\mathrm{Nu}$ bestaan er vele dikke hand-en leerbocken op het terrein van het besturisrecht en wordt het bestuursrecht erkend als een hoofdvak binnen de studie Nederlands recht.

Die groei heeft verschillende oorzaken. In de eerste plaats is er - ondanks alle pleidooien voor deregulering - heel veel positief bestuursrecht. De overheid stuurt en ordent het maatschappelijke leven op vele onderdelen. Op hat gebied van de bijzondere delen van het bestuursrecht zoals omgevingsrecht en sociaal zekerheidsrecht zijn vele wetten voortgebracht.

Een stroomversnelling in de ontwikkeling van het bestuursrecht werd veroorzaakt door de invoering van de wet $\mathrm{AROB}$, administratieve rechtspraak overheidsbeschikkingen, in 1976. De toen ingestelde Afdeling rechtspraak van de Raad van State was de eerste en enige algemene -- algemeen in de zin van bevoegd op het gethele terrein van hed be stuursiecht - administratieve rechter in Nederland. Onder leiding van de cerste voorzitter van de Afdeling, prof mr. J. van der Hoeven, kwam belangrijke jurisprudentic lot. stand.

Een tweede, 20 mogelijk nog belangrijkere impuls voor de ontwikkeling van het bestuursrecht was de invoering van de Algemene wet bestuursrecht (Awb) op I januari 1994 in combinatie met de instelling van bestuurssectoren bij de arrondissementsrechtbanken. Sinds 1994 is de mooie oude term administratief recht in onbruik geraakt en vervangen door de modemere term bestudisrecht.

Niet alleen de praktijk maar ook de wetenschap heeft veel bijgedragen aan de on wikkeling van het bestuursrecht. Tot plusminus 1980 vonden er weinig promoties plaats

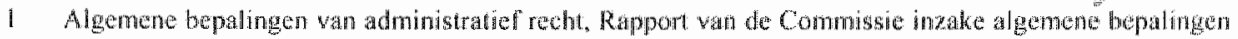

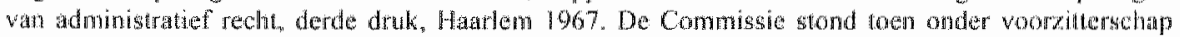

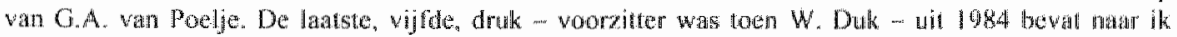

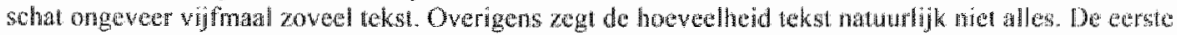

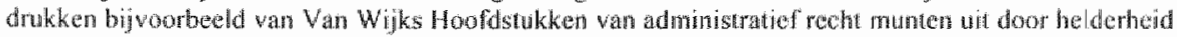
an betsopotheid. 
aan de juridische faculieiten en werd er ook overigens viij weinig gepubliceerd. Maar dat jaar vormde min of meer een omslagpunt. Dit heeft, naar ik aanneem, te maken met een veranderde organisatiestructuur van en mentaliteit op de universiteiten. Kortweg gezegd: werd er tot en met de jaren zeventig door een deel van de staf wellicht te weinig gewerkt, daarna is de situatie doorgeschoten naar de andere kant en staat de wetenschappelijke staf onder een grote publicatiedwang.

Er is sprake van een ratrace. Een negatief gevolg daarvan is dat er teveel achter de actualiteit wordt aangelopen en er te weinig tijd is voor bezinning. Wie neemt er nog de tijd wat oudere handboeken door te nemen? Wie leest bijvoorbeeld nog A.M. Donners Algemeen Deel van het Nederlands bestuursrecht, een boek dat nog steeds zeer relevant is voor een goed begrip van het bestuursrecht. ${ }^{2}$

Helaas is er ook bij veel studenten weinig interesse in het verleden. Alles wat voor het jaar 2000 heeft platsgevonden is geschiedenis en dus niet interessant. Maar een onderwerp als bijwoorbeeld de organisatie van de bestuursrechtspraak is niet goed te begrijpen zonder enige historische kennis.

\section{De relatie met de overige rechtsgebieden}

Opmerkelijk is de toenemende vervlechting van het bestuursrecht met andere rechtsgebieden. In de eerste plats is uiteraard het bestuursrecht nauw verweven met het staatsrecht, ${ }^{3}$ maar ik doel hier met name op de relatie tussen het bestuursrecht en het privaatrecht, strafrecht en Europees recht.

De relatie bestuursrecht-privaatrecht is uitermate boeiend. Op dit gebied hebben wellicht de meest diepgaande discussies plaatsgevonden. Interessant is de tegenstelling tussen de bestuursrechtjuristen met een constitutioneelrechtelijke achtergrond aan de ene kant en de bestuursrechtjuristen met een civiele achtergrond aan de andere kant.

De eerste groep heeft de neiging veel waarde te hechten aan het legaliteitsbeginsel en het eenzijdige en exclusieve karakter van publiekrechtelijke bevoegdheden te benadrukken. De tweede groep daarentegen heef de neiging de overheid als civielrechtelijke rechtspersoon op gelijke voet te behandelen als andere rechtspersonen en de contractsvrijheid voorop te stellen. ${ }^{4}$ Het zal geen verbazing wekken als ik opmerk dat de burgerlijke kamer van de Hoge Raad lange tijd tot de tweede groep behoort heeft. De Hoge Raad heeft lange tijd de zogenoemde tweewegenleer aangehangen. Deze leer houdt kort gezegd in dat het de overheid in het algemeen wrijstal de privaatrechtelijke weg te kiezen, ook als er een publiekrechtelijke weg is. In 1990 is de Hoge Raad omgegaan. ${ }^{5}$ Er zijn beperkingen gesteld aan de tweewegenleer. De Hoge Raad heeft meer oog gekregen voor het exclusieve karakter van publiekrechtelijke bevoegdheden.

2 A.M. Donner, Nederlands bestursrech, Agemeen deel, vijfde en latste druk, Alphen asn den Rijn 1986.

3 Stats- en bestuurstecht vormen én rechsgebied en zijn niet wan elkaar te scheiden. Staatsrecht is niet te begrijpen zonder bestuursecht en vice versa.

4 Het is aardig de handboeken wan Tak (De overheid in liet burgerlijk recht, Den Haag 1997) en de beide Scheltema's (Gemeenschappelijk recht, Dewenter 2003) maast elkaar te leggen. Tak benadrukt de exchisiviteit wan het bestunrstecht, terwijl de beide Scheltema's, zoals de titel wan het boek al atangeef, het gemeens chappeligke wan het bestursrecht en priwatiecht benadrukken. HR 26 jantari 1990. N 1991. 393 m.nt. M. Scheltema (Windmillarrest). 
Een tweede belangrijke ontwikkeling is dat de Hoge Raad vanaf 1987 op contractuele verhoudingen tussen overheid en burger ook de algemene beginselen van behoorlijk. bestuur van toepassing acht. ${ }^{6}$ De wetgever heeft deze leer in 1994 in de Awb neergelegd. Deze leer wordt wel de gemengde rechtsleer genoemd, gemengd omdat zowel privaatrecht als bestuursrecht van toepassing is.

In de discussie tussen beide groepen heb ik altijd aan de kant gestaan van wat ik gemakshalve de constitutionalisten noem. Ik zou ook nog verder willen gaan dan de Hoge Raad, en de tweewegenleer ten principale willen verlaten. Als er een publiektechtelijke weg is dient deze ook gevolgd te worden. Ook van de gemengde rechtsleer ben ik geen voorstander Heit bevordert de duidelijkheid niet. Indien de overheid een bepaald aspect van het algemeen belang wil behartigen, moet er een publieke bevoegdheid worden gecreëerd. In de gevallen dat de overheid van het privaatrecht gebruikmaakt doet zij dat als ieder andere (rechts)persoon. Ik zie geen reden in die privatrechtelijke verhoudingen tussen overheid en burger ook nog bestuursrecht van toepassing te doen zijn. Het moderne privaatrecht biedt ruimschoots voldoende mogelijkheden zwakke partijen te beschermen tegen sterke partijen.

Ik benadruk een scherp onderscheid tussen bestuursrecht en privaatrecht en zie niet de wenselijkheid van het naar elkaar toegroeien van bestuursrecht en privaatrecht. Het introduceren van het begrip wederkerige rechtsbetrekking in de toelichting bij de $\mathrm{Aw}$ vind ik dan ook bepaald ongelukkig. Het begrip rechtsbetrekking en zeker wederkerige rechtsbetrekking suggereert tweezijdigheid en gelijkwaardigheid. Het verdoezelt dan ook het verschil tussen bestuursrecht waar het eenzijdig handelende bestuur optreedt, en het privaatrecht waar contractsvrijheid vooropstaat. ${ }^{8}$

Over de verhouding bestuursrecht-strafrecht en bestuursrecht-Europees recht zal ik korter zijn.

Er heeft een aanzienlijke verschuiving van strafrecht naar bestuursrecht plaatsgevonden in die zin dat er de afgelopen jaren sprake is van cen opmars van de bestuurlijke boete." De wetgever vindt bestuursrechtelijke handhaving in veel gevallen efficiènter en goedkoper dan strafrechtelijke handhaving. Probleem is wel dal punitieve bestuurlijke sancties criminal charges in de zin van artikel 6 EVRM zijn. De nationale bestuursrechtelijke regelingen dienen dan ook te voldoen aan verdragsrechtelijke waarborgen. ${ }^{16}$

Op het terrein van de reparatoire bestuurlijke sancties is de jurisprudentiewijziging van de Afdeling bestuursrechtspraak van groot belang." De bevoegdheid tot het toepassen

6 HR 27 maart 1987, NJ 1987, 727 m.nt. M. Schelicona (IKON-arresi).

7 Art. 3:1 lid $2 \mathrm{Awb}$. Overigens heeft het $\mathrm{KKON}$-arest zijn belang behouden omdat (nog) niet alle algemene beginselen van bethoorlijk bestuur zijn gecodificeerd in de Awb. Onder andere gatdt dit wor thet gelijkheidsbeginsel war het IKON-gurrest betrekking op had.

8 Zie miin bespreking van de dissertate vall Goorden in NTB 1990, p. 295 e.w.

9 F.C.M.A. Michiels, De boete in opmars?, oratie VU, Zwolle 1994,

10 Zie daarover C.L.G.F.H. Albers, Reehtsbescherming bij besturlijke boeten, diss. Matsinchi, Den Haag 2002.

11 Zie hierover C.L.G.F.H. Albers, De beginselplicht tot handhawing. Een nieuwe benadering? "JB phusw 2005, p. 192 e.v. 
van bestuursdwang wordi niet meer gezien als een beleidsvrije bevoegdheld. De Afdeling gaat uit vart eet beginselplicht tot handhaving.

Haast sluipenderwijs, zou ik bujna zeggen, is hel belang van het Europese (bestwurs) recht toegenomen. ${ }^{2}$ Nederland heeft met zijn deelname aan de oprichting van de EEG een deel van zijn soevereiniteit prijsgegeven. Welswar gaat het Europese recht uit van in principe de autonomie wan het nationale bestuursrecht, maar er dient wel aan een aantal voorwaarden te worden voldaan. ${ }^{13}$ En het voldoen aan die voorwaarden kan een diepe ingreep betckenen in het nationale bestwursnecht. En er is zeer veel materieel Europees bestuursrecht dat deel uitmakt van ons nationale bestuursrecht.

\section{De grote wetgevingsoperaties}

In de jaren negentig van de vorige eeuw werd het bestuursrecht beheerst door twee grote wetgevingsoperaties die sterk met elkaar samenhangen, te weten het tot stand brengen van de eerste tranche van de Awb en de integratie van de bestursnechtspraak in de rechterlijke macht. Sinds 1983 bepaalt artikel 107 lid 2 Grondwet dat de wet algemene regels van bestuursecht vaststelt. Het tot stand brengen van algemene regels van bestuursrecht is geen eenvoudige zaak. De mogeljkhieden algemene regels tot stand te brengen zijn vrij beperkt ondat het bestuursrecht uit zoveel bijzondere delen bestaat die naar hun aard sterk uiteenlopen. Denk bijvoorbeeld aan ruimtelijke ordeningsrecht, belastingrecht, ambtenarenrecht. Verdedigbaar is het standpunt dat een algemene wet niet gewenst is omdat de bijzondere delen zó versehillend zijn dat zij alle hun eigen op de bijzondere materie toegesneden wetgeving behoeven. In die visie zouden hoogstens ankele bepalingen nodig zijn op het terrein van doorzend-en/of verwijsplichten om de burgers niet het slachtoffer te laten worden van de ingewikkeldheid van het bestuursrecht.

Dit standpunt wordt echter nauwelijks meer verdedigd. Vrijwel een ieder is overtuigd wan het belang van het bestaan wan een Awb. Argumenten op het terrein van de rechtszekertheid en rechtseenheid spelen daarbij een belangrijke rol.

Do Awo is cen mooi stukje wetgeving geworden. De wet zit wetstechnisch zeer knap in elkat: Toch is ar ook wel wat kritiek te geven.

In de eerste plaats heeft de $A w b$, evenals het $B W$, een zogenaande gelaagde structurur, dat wil zeggen dat de opeenwolgende hoofdstukken van algemene nax meer bijzondere bepalingen gatan. Vaak moet je op drie of meer plaatsen in de Awb kijken on te weten thoe een besluit tot stand dient te komen. Op subsidiebeschikkingen bijvoorbeeld zijn de hoofdstukken 3 (hoofdstuk 3 bevat algemene bepalingen over besluiten, dus ook over beschikkingen) en 4 (titel 4 . I handelt over beschikkingen en titel 4.2 handelt over subsidies) van toepassing. Bovendien dient nog altijd de bijzondere wet geraadpleegd te worden. Die bijzondere wetten zijn nodig vanwege het legaliteitsbeginsel (de bijzondere wet verschaft de bestuursbevoegdheid aan het orgaan) en het gehele materiele be-



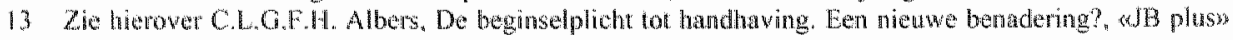
$2005,1920$. 
stuursrecht is gebaseerd op de bijzondere wetgeving. De Awb bevat alleen non-contentieus en contentieus besluitvormingsrecht oftewel formeel recht. Een probleem is nu dat de bijzondere wetten vaak afwijkingen van de Awb bevatten. Dit komt zó vaak voor dat de Awb zelf uitgehold dreigt te worden. Zelfs ervaren bestuursrechtjuristen maken vaak fouten door de gecompliceerde structuur van de $A$ wb en de relatie tot da bijzondere wetgeving. Voor een burger, niet jurist zijnde, is de wet ontoegankelijk.

Een tweede nadeel acht ik de schakelbepalingen, die hierwoor al aan de orde zijn geweest. Schakelbepalingen bevorderen niet de rechtszekerheid.

Het is evident dat een algemene wet bestuursrecht alleen zinvol is indien deze wet uniform wordt toegepast en geïnterpreteerd. Het merkwaardige is echter dat er een groot aantal rechterlijke instanties is dat de Awb in hoogste instantie toepast en uitlegt. ${ }^{14}$ Weliswaar vindt er (informeel) overleg plaats tussen die colleges, maar afgezien van de constitutionele bezwaren die men daartegen kan aanvoeren ${ }^{15}$ leidt dat overleg niet altijd tot overeenstemming. ${ }^{16}$

Velen gingen er begin jaren negentig van de vorige eeuw nog vanuit dat de bestuursrechtspraak volledig zou worden geintegreerd in de rechterlijke macht. ${ }^{17}$ De bestuursrechtspraak had zich in de twintigste eeuw stapsgewijs en verbrokkeld ontwikkeld, grotendeels buiten de rechterlijke macht om.

De Staatscommissie Van Zeben had begin jaren tachtig het ei van Columbus gevonden, namelijk: behandel het bestuursrecht zoals het burgerlijk recht en het strafrecht, dat wil zeggen in principe twee feitelijke instanties en cassatie. ${ }^{18}$ De integratie van de bestuursrechtspraak in de rechtbanken is tegelijk met de invoering van de Awb grotendeels gerealiseerd. Dat was van groot belang, onder andere vanwege de ontlasting van de Raad van State. Helaas is de verdere integratie om allerlei politieke en financiële redenen geblokkeerd. Het resultaat is dat we met een ongekeerde piramide zitten: eenheid aan de basis, verscheidenheid aan de top, terwijl de omgekeerde situatie zoals we die kennen in de omringende landen tach meer voor de hand ligt. ${ }^{19}$

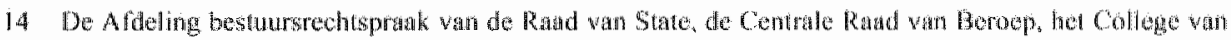

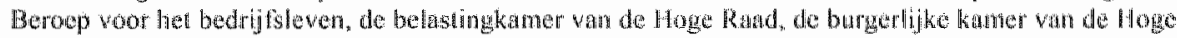

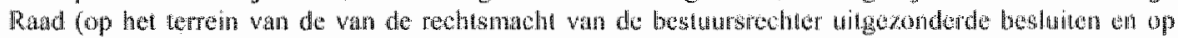

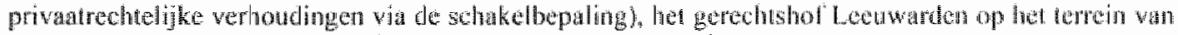

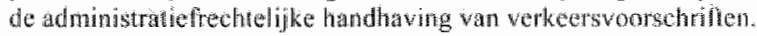

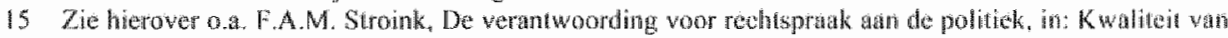

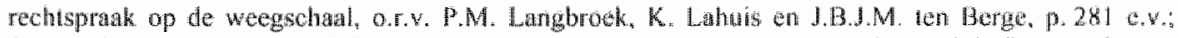

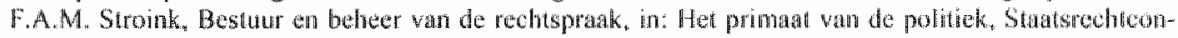


bij onthinding wan de ritbeidsovereenkonst. Social Rech, 1907. p, 32 e.v.

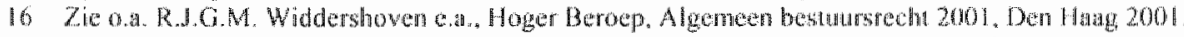



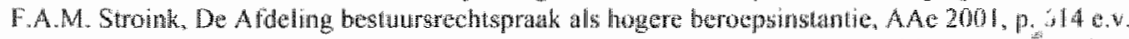

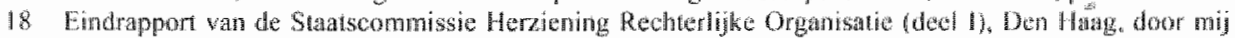
besproken in mijn Hexterise oratie Administratieve rechtsprakk en rechter ijke mach. 2 wolle 1985.

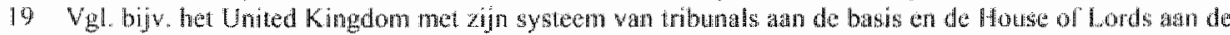

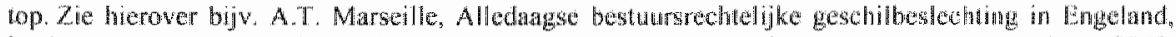


p. 69 e.v. 
Ik ben nog steeds een voorstander van verdere integratie. Het beste systeem lijkt mij dat de wijf gerecthtsoven alle een aantal bijzondere delen voor hun rekening nemen. Dat betekent dat wat betreft het materiele bestwursrecht de eenheid wordt gegarandeerd op het nivea van het hof. Cassutic bij de Hoge Raad, eventueel met de invoering van een zogenoemd verlofstelsel, zou alleen mogelijk moeten zijn op het terrein van het algemeen deel (de Awb en ongeschreven rechtsbeginselen).

\section{Knelpunteri}

Ondanks de grote ontwikkeling van het bestuursrecht in wetenschap en praktijk is er nog wel een aantal knelpunten dat om oplossingen vraagt. Ik noem er enkele.

- nodig is cen verbeterde toegang tot de rechter en een betere competentieverdeling tussen burgerijke rechter en bestuursrechter op het gebied van de schadevergoeding zowel op grond van rechtmatige als onrechtmatige daad. De VAR-Commissie rechtsbescherming pleit voor het inwoeren van een verzoekschriftprocedure. ${ }^{20}$

- nodig is het tot stand brengen van coordinatiebepalingen (de én-loketgedachte) on de nadelen van het specialiteitsbeginsel op te vangen. ${ }^{21}$ De cie.-Scheltema heeft op dit punt een woorontwerp tot stand gebracht. ${ }^{22}$

- de verhouding bestuur-rechter met name op het punt van de mate van intensiteit van de rechterlijke toetsing mede in het licht van de verhouding centralisatie decentrallisatie. Dat is een hele mondvol. Ik ben voor een "sterke" rechter als tegenwicht tegen het duo wetgever-bestuur. Tegelijkertijd hecht ik aan de klassieke zuivere verhouding bestwur-rechter indien er sprake is van beleidsvrijheid. Dan is terughoudende toetsing op zijn plaats en moet de rechter de bestuurlijke vrijheid respecteren. Dat is ook de benadering van de bestuursirechter. ${ }^{23} \mathrm{p}$ deze benadering van de rechter is wel kritiek geuit. De burger zou meer gebaat zijn met een intensievere toetsing. Ik meen dat deze roep om intensievere toetsing voortkomt wit een behoefte aan compensatie voor 'zwak' bestuur. De oplossing is echter niet intensievere toetsing, maar verbetering van de kwaliteit van het bestuur. Daar is uiteraard wel andacht voor goweest matr nar mijn mening te weinig. In het staats - en bestuursrecht is de discussie decentralisatie-centralisatie (op welk niveau kunnen bepaalde bevoegdheden het best worden uitgeoefend) onderbelicht gebleven. Wellicht heeft dat te maken met het feit dat met de mond de gedachte van de decentralisatie beleden werd terwijl er een sluipende centralisatie plaatsvond. Ook heeft naar mijn mening de werkgroep Van Kemenade de discussie enigszins op het verkeerde been gezer. ${ }^{24}$ the begrip woor bestuurders die willen besturen, doeleinden realiseren en zich in hun werk gehinderd voelen, maar het is wel erg eenzijdig van de werklousing nan geschilbesleching. Den Hag 2004. De commiss atond onder voorzitterschap wan J.E.M. Polak

21 R.JN Schussels, Het speciallitetsbaginsel, diss. Maastricht, Den Haag 1998.

22 Voonontwom samenhangende besiuitem Awbl.

23 ABRwS 9 mei 1996, JB 1996, 158, m.nt. F.A.M. S, JB Select, Den Hang 2004, 12 m.nt. F.A.M. S.

24 Wenkroep Von Kemenade, Bestun in geding (Rapport van de werkgroep inzake tongdrimging kan de jundisering van het openbar bestuun), Harten 1997 (niet officiel gepubliceend). 
groep Van Kemenade alle schuld te leggen bij de wetgever (te complexe regelgeving), de rechter (te intensieve toetsing) en de burger (te veel gebruik of misbruik maken van inspraak-, bezwaar- en beroepsmogelijkheden). Verbetering van de kwaliteit van het bestuur zou al veel problemen oplossen. De werkgroep Van Kemenade onderschat met name de positie van de burger. Zij onderschat dat de uitoefening van publiekrechtelijke bevoegdheden vaak gepaard gaat met ingrijpende beperkingen van de eigendoms- en contractsvrijheid van de burger. De burgers hebben die beperkingen te dulden ondat het bestuur het door de wetgever geconcretiseerde algemeen belang heeft te realiseren. Maar de burger heeft er wel recht op - ik kom daar hierna op terug - dat het bestuur zijn bevoegdheden rechmatig uitoefent. In de inherente spanning tussen algemeen belang en individueel belang ligt de charme van de beoefening van het bestuursrecht.

- een oude wens die moeilijk te realiseren lijkt is verminderde regelsdruk en vereenvoudigde regelgeving.

- een laatste door mij te noemen knelpunt - er zijn er meer - wil ik wat uitgebreider behandelen. Dat betreft de omvang van het geschil en in verband daarmee de wens van finaliteit, tijdigheid en - wederom - de intensiteit van toetsing.

Het betreft een lastig probleem dat enige inleiding vergt.

In de toelichting bij de Awb is relatief veel aandacht besteed aan de functies van het bestuursprocesrecht. Van oudsher werden twee functies toegekend aan het bestuursprocesrecht: de rechtsbeschermingsfunctie en de toezichtsfunctie. ${ }^{25}$ In het verleden nam de toezichtsfunctie een belangrijke plaats in. De toezichtsfunctie houdt in dat de rechter bewaakt dat het objectieve recht gehandhaafd wordt. De rechtsbeschermingsfunctie spreekt voor zich. Ik heb al eerder betoogd dat de tegenstelling relatief is. ${ }^{26}$ War het om gaat is dat de rechter de rechtmatigheid van de bevoegdheidsuitoefening toetst en uiteraard ook nagaat of er überhaupt een bevoegdheid is. Of je dat nu bekijkt vanuit het oogpunt van het individuele belang van de burger of vanuit het algemeen belang dat het positieve recht gehandhaafd wordt, maakt niet uit. Het gaat om twee kanten van dezelfde medaille.

Wel zouden er positiefrechtelijk verschillende accenten gelegd kunnen worden, alhankelijk van welke functie men laat prevaleren. Wanneer de toezichtstunctie centraal wordt gesteld zou het voor de hand liggen reformatio in peius (dat wil zeggen dat de appellerende burger door de rechterlijke uitspraak in een slechtere positie komt) en ultra petita gaan (dat wil zeggen dat de rechter ook - ambtshalve - niet bestreden onderdelen van een besluit toetst) mogelijk te maken. Immers het algemeen belang prevaleert in die visie boven het individuele belang. Hoewel oude wetgeving waar de toezichtsfunctic centraal stond één en ander mogelijk maakte, vermeed de rechter al lang wóór 1994 refor-


en de recours subjectif kert. Bij de recours objectif stat de rechmatighe dstoensing wan een bestreden:

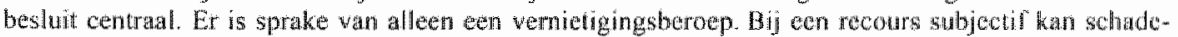

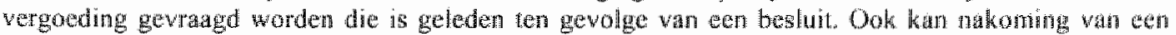
administratief contract gewragd worden. Een situatie die we in Nederland niel kemen. In Nederland is de burgerljke rechler bavoegd inzake overeenkomsten wusgen besuur en burger.

26 F.A.M. Stroink. Kern wan de besiunrstehisprak, derde dnuk, Den Haag 2004, p. 17 e.y. 
matio in peius on ulltra petita gewan. ${ }^{27}$ Een ander mogelijk verschil zit hem in de toegang tot de rechter. Vanuil de toezichlsfunctic geredeneerd is een ruime toegang mogelik en wenseljk (m principe zelfs en actio popularis). Vamüt de rechtsbeschemingsfunctie ligt het voor de hand alleen diegene die in zijn rechten wordt getroffen een beroepsrecht toe te kemen. ${ }^{28}$ Artikel 1:2 Awb ademt nog de oude toezichtsfunctie. In de toelichting bij de A wb wordi echter witd rakkelijk gesteld dat de rechtsbeschemingsfunctie centraal stat en dat de toezichtsfunctio niet of nawwelijks meer een rol speelt.

Merkwardigerwijs heeft dit standpunt geleid tot een situatie warin, naar mijn stellige overtuiging, de rechtsbescheming ten opzichte van de situatie van vóor 1994 verminderd is. Wat is er gebeurd? Vóor 1994 werd als wordering gezien de vernietiging van de bestreden beschikking of een bestreden onderdeel van de beschikking. Daartoe dienden gronden te worden aangevoerd. Axn die gronden werden niet al te hoge eigen gesteld. Bovendien wulde de rechter de gronden an (ambtshalve aanvulling van rechtsgronden en ambtshalve toetsing vielen samen). De omvang van het geding werd bepaald door de bestreden beschikking of het bestreden onderdeel. Na 1994 - het heeft wel enige jaren geduurd woordat een en ander duidelijk werd - wordt de omvang van het geding bepaald door de angevoerde gronden. ${ }^{29}$ Ambtshalve getoetst wordt er uitsluitend aan bepalingen van openbare orde en het begrip ambtshalve aanvulling van rechtsgronden wordt eng geinterpreteerd, althans door de Afdeling bestuurstechtspraak (art. 8:69 lid 2 . Awb). Dit betekent alleen maar een vertaling van de door de appellant aangevoerde feitelijke gronden in juridische gronden. Het lijkt mij echter een beperkte opvatting dat het geschil wordt bepaald door witsluitend de aangevoende gronden. Waar het de burger om gaat is dat een besluit van tafel gat, gewijzigd wordt of dat hij na een weigering een positef besluit krijgt: Op welke gronden hij gelijk krijgt zal hem worst wezen. Door deze houding is de rechter minder actief en vervalt de zogenoende ongelijkheidscompensatie. Van de burger word verwacht dat hij de juiste gronden aanvoert, terwijl. er geen sprake is van verplichte procesvertegenwoordiging. Laat hij in bezwaar bepaalde gronden achterwege dan bestaat de kans dat hij daarvoor bij de rechtbank wordt afgestraft (de grondenfuik). ${ }^{30}$

Verwant an de discussie over de omwang van het geschil is de discussie over, wat ge noemd wordt finaliteit en tijdigheid. Met finaliteit wordt bedoeld dat met rechterlijke uitspraak het geschill definitief beslecht wordt. Is dat dan niet per definitie 20 , zal een argeloze burger, welfs menig civicl- en strafrechtjurist opmerken. Nee, dat is - helaas niet 20 . Indien wordt wemietigd op grond van zogenoemde formele gronden (motive-

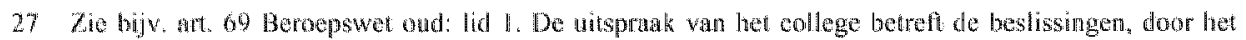

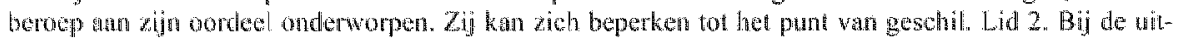

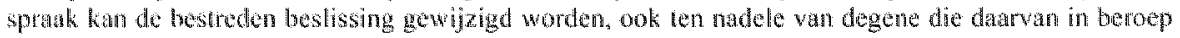
is gekomen.


geschonden zijh on boegang tot de bechurrechter te krigen. Zie 42 lid 2 VwGO

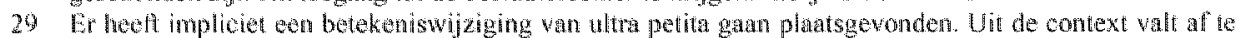
leiden dat ved atteurs an muelujh onder werstan toetsen an andere beroepsgronden dan de aangevoerde in plands wh niel bestheden anderdelen wan het besluit toetsen.




ABRWS. Aie onder theer dio noot wan Widdershowen bij ABR 12 janturi 2005, AB $2005,75$. 
ringsgebrek, gebrek in de zorgvuldige voorbereiding van een besluit) dan kan llet zijn dat er een ander inhoudelijk besluit uit de bus valt, maar het is ook mogelijk dat het bestuur een nieuw besluit neemt dat inhoudelijk identiek is aan het vemietigde, matr nu beter gemotiveerd en beter voorbereid. ${ }^{31}$ Het behoeft geen betoog dat dit voot de appellerende burger uitermate frustrerend is. Men denkt gewonnen te hebben, mat witeindelijk heeft men toch de zaak én tijd verloren.

Is dit verschijnsel te voorkomen of inherent aan het wezen van bestuursrechtspraak, te weten rechtmatigheidstoetsing van een besluit? ${ }^{32}$ In veel gevallen zal de rechter door een actievere opstelling vernietiging op formele gronden met de reéle mogelijkheid dat het bestuur inhoudelijk opnieuw hetzelfde zal besluiten, kunnen voorkomen.

Onderzoek van Marseille heeft uitgewezen dat in veel gevallen er onenigheid bestaat over de vaststelling van de feiten en de kwalificatie van de feiten. ${ }^{33}$ Door zich actiever op te stellen in het vooronderzoek kumnen de gebreken boven water komen en hersteld worden. De rechter kan tijdens het vooronderzoek partijen oproepen (art 8:44 Awb), schriftelijk inlichtingen vragen aan partijen en anderen (art.8:45 Awb), getuigen oproepen (art. 8:46 Awb), deskundigen benoemen (art. 8:48 Awb) en een onderzoek ter plaatse instellen (art. 8:51 Awb). De rechter heeft ook de mogelijkheid de omvang van het geschil te sturen. Hij moet weliswaar uitspraak doen op grondslag van het beroepschrift, maar ook op grondslag van de overgelegce stukken, het verhandelde tijdens het vooronderzoek en het onderzoek ter zitting (art. 8:69 lid 1 Awb). Uit het onderzoek van Marseille blijkt ook dat de rechter (te) weinig gebruik maakt van zijn onderzoeksbevoegdheden. ${ }^{34}$ In veel gevallen zal actiever vooronderzoek bewerkstelligen dat duidelijk wordt hoe het nieuwe besluit dient te luiden. Als de rechter niet zelf in de zak kan voorzien, dan is voor de burger in ieder geval duidelijk hoe het nieuwe bestuursbesluit zal luiden. En dat is winst.

Ik hoor als kritiek al dat een en ander te veel zal vergen van de rechter en tot overbelasting zal leiden. ${ }^{35}$ Inderdaad zal uitbreiding van de bestuurssectoren nodig zijn. Maar ik ben ervan overtuigd dat de winst (bevrediging van het rechtsgevoel van de burger, duidelijkheid, tijdwinst) opwegen tegen de kosten. Ik zou zelfs nog een stap verder willen gaan.

In een aantal gevallen zal een intensiever rechterlijk vooronderzoek niet tot de gewenste duidelijkheid leiden. Bijvoorbeeld, indien er sprathe is van beleidsvijheid is het

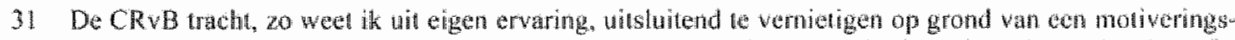


kritick is met name gerichut op de Afdeling (bastuurs)rech sprak.

32 De ondertiel van he rapport wan de VAR-Commissir rechtsbescherming "Wan loetsing maj


geschil beslech door toetsing ven en besluit.

33 A.T. Marseille. Effectiviteit van bestuursrechisprak. Ean onderzoek naar het verloop on de uikomst

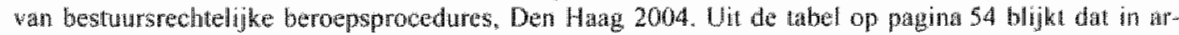
beidsongeschiktheidszaken $81^{\text {or }}$ wan de beroepschrifen betrekhing heell op de vasistelling wan de feiten en $40 \%$ op de kwalifatie van de feiten. In bouwzaken liggen deze percentages op 29 resp. $71 \%$.

34 Zie de tabellen op de pagnat $54-76$.

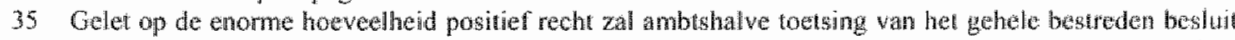
zeer veel wid kosten. Een rechter weet echter wit ervaring veelal wel wat de probleman zitucn. Wellicht

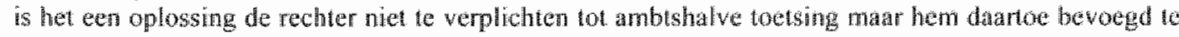

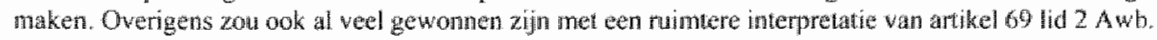


mogelijk dat het bestuur en hernieuwde belangenafweging dient te plegen. In het huidige system is vernietigen en terugverwizen de enige oplossing. Aan Schueler komt de eer toe als eerste cen oplossing voor dit probleem bedacht te hebben. ${ }^{36}$ Het kont erop neer dat in dit soort gevallen de rechter de zalk aanhoudt, het bestuur een nieuw (concept)besluit neemt ${ }^{37}$ en de rechter dit nieuwe (concept)beshuit meeneemt. ${ }^{38}$ Ook hier is uiterata de kritiek mogelijk van rechterlinke overbelasting.

Een groot voordeel van deze zogenoemde besturlijke lus is dat de verhouding bestuurrechter zuiwer bliff: De rechter behoeft niet intensiever te gaan toetsen en op de stoel van het bestuur te gaan zitten. Het initiatief en de verantwoordelijkheid blijven bij het bestuur omdat het bestuut een nieuw (concept)besluit neemt.

Het toepassen van deze bestuurlike lus kan op gespannen voet komen te staan mel de huidige rechterlijke opvatting over de omvang van het geschil. Een voorbeeld kan dit verduidelijken. ${ }^{39}$

De NV Versatel Telecom Intemational had aan de statssecretaris van Financièn met een beroep op de WOB verzocht om inzage in, athans geanonimiseerde overlegging van afspraken en rulings inzake aandelen-optieplannen, die de belastingdienst Grote ondernemingen Amsterdam in de periode 1998-2000 heeft gemalki met respectievelijk getroffen voor ondertiemingen met het voomemen tot een beursgang en om informatie omtrent het door voomoemde dienst ten aanzien van personeelsopties in dat verband gevoende beleid. De staatssecretaris heef dit verzoek afgewezen en het bezwar ongegrond verklaard. Naar het oordeel van de rechtbank heeft de statssecretaris een onjuiste grond aan de weigering ten grondslag gelegd. De rechtbank is van mening dat andere gronden de weigering wel kunnen dragen. Een en ander leidt juridisch-technisch tot gegrondwerklaring wan het beroep maar met instandlating van de rechtsgevolgen van het bestreden besluit. Een mooi voorbeeld van een definitieve geschilbeslechting door de rechtbank. Partijen weten meteen waar ze aan toe zijn. Een uitsluitende beoordeling van de aangevoerde grond gewolgd door vernietiging zou leiden tot een identiek inhoudelijk nieuw beshuit door de stantssecretaris met als gevolg wellicht een nieuwe procedure.

Helaas werd deze weikwijze van de rechtbank afgestraft door de Afdeling bestuursrechtspuak. Nat het oordeel van de Afdeling is de rechtbank buiten de omvang van het gerezen geschil getreden omdat zij de vernietiging niet heeft gebaseerd op een beoordeling van het bestreden besluit en de daarvoor gegeven motivering, maar op het doot de rechtbank daarvoon in de plaats gestelde oordeet. Het behoeft geen betoog dat ik in casu de omvang van het geschil rumer wil zien, niet de weigering op grond $X_{*}$ maar de vragg of al dan niet terecht geweigend is.

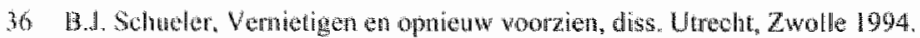

37 At. 6:18 lid I Awb bied woo het bestum de mogelijkeid in bepalda gewallen tijdens het bezwar of beropen besluit in te trekken of te wijzigen. De reetuter kan dat echer niet opleggen an het bestuut.



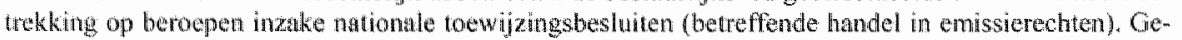
theth wondt an een algemene regeting in de Awlo. Wellicht reds met ingang wan 1 jantari 2007 , aldus ministar Donne in anowond op 19 okiober 2004 op ean datoe strokkende vaag van de rweede

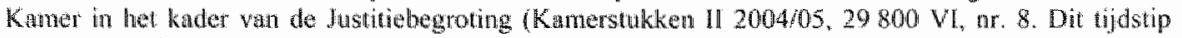
Hijke mij wel rijkelijk vowg. 
Kort samengevat komt mijn pleidooi op het volgende neer:

- een actievere houding van de bestuursrechter,

- een ruimtere opvatting over de omvang van hel geschil,

- een wettelijke mogelijkheid om het geschil definitief te kunnen afdoen.

De kosten die dit met zich brengt worden ruimschoots gecompenseerd door een meer bevredigd rechtsgevoel van de burger en meer tijdwinst. Een actievere houding van de rechter leidt ook tot kwaliteitswerbetering van het bestum wat (ook) in het algemeen belang is. Ook dient meer aandacht te komen voor kwaliteitsverbetering van het bestuur. Dit leidt tot meer legitimiteit van het bestuur en tot een verminderde druk op de rechter. Beroep op de rechter hoort uitzondering en geen regel te zijn.

Ik ben aan het einde gekomen van mijn afscheidsrede. Uiteraard heb ik slechts enkete problemen uit het bestuursrecht kunnen aanstippen.

lk heb in mijn universitaire leven met veel mensen samengewerkt en veel mensen hebben mijn denken beînvloed. Ik hecht eraan enkele namen te noemen zonder anderen tekort te willen doen.

Zeer vruchtbaar waren mijn tien Utrechtse jaren. Ik noem prof.mr. J.G. Steenbeek, mijn promotor, prof.mr. M.C. Burkens, prof.mr. J.B.J.M. ten Berge, profmr. B.W.N. de Waard en mr. C. Crasborn. Aan hen heb ik veel te danket. Met allen heb ik contacten onderhouden na mijn vertrek uit Utrecht.

Bij de Open Universiteit heb ik geleerd niet alleen onderwijzer en onderzoeker to zijn, maar ook manager.

De juridische faculteit te Maastricht is altijd een zeer aangename werkplek geweest. Ook hier heb ik met velen samengewerkt en heb ik veel vriendschappen opgedaan. $\mathrm{k}$ volsta met het memoreren van mijn diepbetreurde vriend Ad Geers.

Het schenkt mij voldoening dat twee van mijn tien promoti al geruime tijd het hoogleraarschap bekleden, Rob Widdershoven te Utrecht en Raymond Schlössels te Nijmegen.

Ik ben nog niet helemaal weg uit Maastricht. Ik hoop nog een aantal jaturen een kleine bijdrage te kunnen leveren aan de verder ontwikkeling van het vakgebied binnen de capaciteitsgroep publiekrecht.

lk heb gezegd. 